\title{
Templates for financial control? Management and employees under the private equity business model
}

\author{
Ian Clark, University of Birmingham \\ Human Resource Management Journal, Vol 23, no 2, 2013, pages 144-159
}

The term 'private equity business model' (PEBM) refers to private equity investors that delist publicly quoted firms, managing them as private equity-controlled portfolio firms. But how and in what form do these investors diffuse a preferred template for the PEBM in portfolio firms? Is diffusion codified, institutionalised or merely tacit? What is the difference between these forms of diffusion? As a method of financial control, how is diffusion evident for managers and workers? Theoretically, while 'financialisation' is a contemporary pressure on the British economy, there is a 'disconnection' between competitive pressures for financialisation and the diffusion of practices to manage these pressures in portfolio firms. Forty-two interviews in eight portfolio firms and five associated private equity firms concludes that potentially transformative and decisive restructuring for managers and workers is more evident than a defined template.

Contact: Dr Ian Clark, Department of Management, University of Birmingham, University House, Edgbaston, Birmingham B15 2TT, UK. Email: i.a.clark@bham.ac.uk

\section{INTRODUCTION}

$\mathbf{T}$ he term 'private equity business model' (PEBM) describes buyouts where large private equity funds buy and delist established firms. These buyouts are substantially different from venture capital buyouts and mid-market buyouts by managers and outside investors that aim to roll out and further develop small- to medium-sized firms. This article demonstrates both theoretically and empirically that the PEBM has a potentially transformative effect on management practice in (what become) portfolio firms. This transformative effect emphasises financial control in portfolio firms in the interests of outside owner-investors that specialise in taking listed firms private to restructure established, that is, publicly quoted, firms (Morgan, 2009; Wilson et al., 2010). Acquisitions supported by the PEBM represent 30 per cent of all private equity acquisitions in the UK. Across the European Union (EU), buyouts of existing businesses account for 70 per cent of the value all private equity investment (PSE, 2007: 45, WEF, 2008: viii; Gilligan and Wright, 2010: 14). In 2008, transactions utilising the PEBM represented 39 per cent of all private equity deals, slightly down from 42 per cent in 2007, returning to 40 per cent in 2009 (CMBOR, 2008, 2010a,b). This article examines the PEBM in the context of the financialisation of the British economy and the manner in which financialisation is diffused in portfolio firms and the effects of this on firm level HR practices.

The research method focuses on the PEBM as a business model that promotes tighter financial control in firms that is predicated on generating improved investment returns and financial control for business owners. The contribution of this article lies in the examination of two research questions. First, how and in what form do private equity firms (PEFs) diffuse a preferred template for the PEBM in portfolio firms (PFs)? That is, is diffusion codified, institutionalised or merely tacit? And what is the difference between these forms of diffusion? This is an important question to test for two reasons. On the one hand, several critical contributions to the literature on the PEBM establish that these investors have a preferred 
template to restructure portfolio firms that may or may not be implemented (Thornton, 2007: 24-25; Folkman et al., 2009). On the other hand, across Europe, while this template includes measures such as asset sales, trade union derecognition, redundancy, downgrading information and consultation mechanisms and employee transfers, the use of the PEBM is adapted to national patterns of industrial relations. That is, the PEBM is not a universal threat to industrial relations within the European social model, but it may nevertheless be more of a threat in the UK (Bacon et al., 2010; Clark, 2010). Two, as a method of financial control, how is diffusion evident for managers and workers? That is, how are hypothesised causal variables such as the PEBM template experienced by employees in portfolio firms?

The article is structured as follows. The first part further defines the PEBM and reviews the literature on the private equity sector and the innovatory effects of the PEBM. The second part focuses on a 'disconnection' between competitive pressures towards financialisation as a contemporary driver in the British economy and the formal diffusion of practices for financial control associated with the PEBM in portfolio firms owned and controlled by PEFs. These pressures may lead to the diffusion of longer term value-adding resource-based approaches to business and HR strategies. However, the embedded presence of more minimalist approaches to the inclusion of the HR function in formulation of business strategy may inhibit or disconnect such an approach. The third part reviews the research methods used in this study. The fourth part examines the transformative effect of the PEBM on management practice in eight portfolio firms. The fifth part concludes on the findings presented in the article.

The examination is based on interviews with managers in these firms and interviews in five associated PEFs each of which is a majority investor-owner in one of the portfolio firms. The article adds to existing knowledge in two ways. First, the research presents 'views from below' in portfolio firms. Conducting research at this level is in contrast to many other studies on the PEBM, which as several contributors suggest concentrates on survey material gathered from PEFs provided by or on behalf of the British venture capital and private equity association (see Froud and Williams, 2007: 409; Folkman et al., 2009: 519; Morgan, 2009: 217). Second, many survey-based studies that highlight movement towards resource-based approaches for the management of HR, while rigorous in method, have very low response rates in the region of 7 per cent (see Bacon et al., 2010). In comparison, the findings from eight case studies are able to identify in-depth the extent to which a defined template for management change and restructuring in portfolio firms is actually diffused.

\section{PRIVATE EQUITY: THE SECTOR AND THE PEBM}

The private equity sector has three segments: venture capital, mid-market buyouts of private firms, and the focus of this article, funds that specialise in taking listed firms private via the PEBM to restructure established, that is, publicly quoted firms (Morgan, 2009; Wilson et al., 2010). Once a private equity investor has the majority control of a listed portfolio company, it is the dominant shareholder, and shares may no longer be traded. PEFs buy listed firms the way that individuals purchase houses, that is, with a deposit supported by mortgage finance often in the form of 'balloon mortgages', where the size of payments grows over time. However, a critical difference is that homeowners pay their own mortgages whereas the PEBM ensures that portfolio firms take out these loans making them and not the private equity investors responsible for the loans, both as a portfolio firm and when the private equity investors have sold the firm. PEFs use leverage to extract value for investors and shareholders, arguing that loading up portfolio companies with debt leads to a more efficient allocation of capital and risk constraining discretionary management strategies, disciplining managers and increasing portfolio company earnings. This 
may or may not be true, but the key point is that the debt remains with the portfolio firm business once the private equity investors have divested themselves of the firm. If the debts become less serviceable, 'the going concern' status of a business may be called into question as the recent case of Southern Cross care homes demonstrates.

Private equity investors raise capital from investors who commit monies to a private equity fund for a defined period of time, usually 10 years. Fund managers invest in organisations that become portfolio firms, that is, a firm or entity in which a private equity fund invests on behalf of its own investors. The use of the term 'portfolio firm' reifies the idea of an dormant investment portfolio to 'living' firms that supply goods and services, employ labour and include diverse stakeholder interests. Beyond a transaction that denotes a change of ownership, a distinguishing feature of the PEBM is its potential transformative effect on management practice in portfolio firms. One measure of this potential transformation is decisiveness of management restructuring and the capability of private equity owners to generate cash for institutions that have invested in their funds. This is sometimes referred to as a focus on short-term performance. Transformational change and development in portfolio firms often promotes direct ownership interests and focuses on incentivising managers to behave like owners by the use of performance management systems linked to share prices and to share option schemes (Jensen, 1989, 2007). This focus ushered in short-termism as a priority for performance management metrics in portfolio firms. Fused with a 'downsize and distribute' approach to business and HR strategies, this priority promotes lower levels of employee entitlement as one source of immediate improvement in financial returns for investors and shareholders (O'Sullivan, 2000; Thompson, 2003; Clark, 2009a). A defining feature of the PEBM is that investors can use portfolio firms to extract value for themselves and their investors but can escape any long-term liability for this debt. The PEBM represents a method of business control where investors in a fund and the partners overseeing the PEBM and its deployment in portfolio firms are wholly separate, both operationally and contractually from a portfolio firm. The PEBM is distinguishable from venture capital as in the main venture capitalists do not rely on leverage debt to support acquisitions (see Gilligan and Wright, 2010).

Some contributors to the literature argue that the PEBM poses a distributional question where a restructuring template can extract value by focusing efficiency on downsizing the scale and scope of assets and commitments and entitlements to existing stakeholders particularly labour (Froud and Williams, 2007; Thornton, 2007; Morgan, 2009). This process may breach implicit contracts between the now portfolio firm and its stakeholders. Theoretically, stable enterprises depend on the existence of implicit contracts between all stakeholders, which are based on trust and designed to minimise opportunistic behaviour (Schliefer and Summers, 1988: 34). Private equity investors who use the PEBM and who are eager to realise quick returns may intentionally or unintentionally repudiate implicit contracts between owners and other stakeholders and achieve private gain from the default on stakeholder claims (Thompson, 2003: 366-368). This behaviour is opportunistic and promotes a unitary expression of what works to 'make money' between managers and owners, in effect, an investor and shareholder conception of financial control in the firm (Fligstein, 2001; Dobbin and Zorn, 2005). Therein, short-term financial gains for investors are secured by extracting value from employees or suppliers where these stakeholders experience draconian restructuring towards a more 'minimalist organisation' (Rodrigues and Child, 2010: 1324-1325). This more minimalist approach can undermine implicit, trust-based relations with skilled employees, vendors, creditors, suppliers or customers on which a firm depends for ongoing business activity (Appelbaum et al., 2011). In contrast to this view, other studies suggest that portfolio firms governed by a template for the PEBM can exhibit a strategy of renewing value. Here, an injection of cash from outside 
owner-investors can overcome the limitations of previous ownership templates often pushing a firm in the direction of resource-based approaches to managing business strategy and HR (see Bacon et al., 2010). Recent reviews of the published studies on private equity buyouts conclude that the employment, wage and HRM effects of buyouts on work organisation, management and employees are mixed but not necessarily negative whereas the efficiency effects of buyouts are more clearly positive (Morgan, 2009; Wright et al., 2009).

\section{THEORETICAL BACKGROUND: INSTITUTIONALISING TEMPLATES FOR FINANCIAL CONTROL AND THE IMPACT OF FINANCIALISATION}

Potential organisational change and development in portfolio firms backed by the PEBM reflects a prevailing wisdom among institutional investors and financial economists that instinctively managers and employees are prone to opportunistic, self-serving irrational behaviour at the expense of investors and shareholders (Jensen, 2007). A central operating presumption of the PEBM is that active owner-investor engagement not only creates the market for corporate control but also promotes efficiency by incentivising managers to explicitly act in the interests of investor-owners (Jensen and Murphy, 2009). What is not in doubt is that within portfolio firms, the pursuit of investor and shareholder value is a primary managerial objective of investor-owners. This development demonstrates the extent to which the British economy is subject to 'financialisation'. 'Financialisaton' refers to structural change in capitalist economies wherein the role of finance capital comes to dominate economic and financial activity beyond financial markets in the operation of economies (Epstein, 2005: 3; Dore, 2008; Clark, 2009b). Therein, new financial actors adopt innovative mechanisms of value extraction as the financial sector acquires autonomy over the real economy. This autonomy is manifest in an emergent pattern of accumulation where profit results from financial markets and associated financial instruments rather than trade in commodity production (Krippner, 2005). Therein, innovative financial instruments, such as securitisation and the collateralisation of pension funds, create a range of 'fictitious' capitals backed by only paper promises.

The literature on financialisation is not a coherent hole but a loose set of arguments that emphasise different developments that nevertheless can be summarised under three headings. First, the key business driver for firms is investor and shareholder value often to the exclusion of other stakeholders (Epstein, 2005). For some, it is often the case that this predominance reflects not only the size of the financial sector but also the rise of financial intermediaries, so-called new financial actors in hedge funds or private equity, which represent the interests of institutional investors (Folkman et al., 2007). The financial services sector has captured a growing share of corporate profits in both the US, where its share grew from 25.7 per cent to 43 per cent between 1973 and 2005, and in the EU 15, where its profit share grew from 21 per cent to 36 per cent between 1970 and 2005 (see Palley, 2009: 4; Watt and Galgoczi, 2009: 192). A second development leading to financialisation is the importance of short-term profits as a focus for investment actors across the economy. Therein, investment strategies of institutional investors have shorter time horizons than previously and while institutional investors may refer to themselves as long-term investors, it is the long-term interests of their clients, for example, pension funds, hedge and private equity funds, which they are concerned with not necessarily the portfolio firms they invest in (see Goyer, 2006: 401). Directly related to this development is the emergent preference within the British economy for growth of the firm via merger and acquisition and takeovers. A third development leading to financialisation is the arrival of more or less permanent financial engineering as a core competence in businesses as non-financial firms identify short-term fluctuations in stock market valuations and the market 
for corporate control as determining factors in corporate strategies (Thompson, 2003; Dore, 2008; Clark, 2009a). This development changes the basis of competitive rules as the interests of owners predominate over those of the portfolio firm; see also Bogle (2005), Dore (2008: 1104) and Folkman et al. (2007).

While the British economy exhibits short-termism, institutionally therein management has proved capable of rapid diffusion of new business models and associated business strategies (Sisson and Purcell, 2010). Even so, while the British economy exhibits short-termism, this characteristic is itself disrupted and reshaped by financialisation in three ways. First, new owner-investors view investment in a portfolio firm as a transaction in itself where achieving significant financial returns from such transactions is disconnected from the production or provision process in portfolio firms (Soros, 2008). For portfolio firms, this development may further weaken the commitment of British employers to management development. Second and directly related, contemporary financial demands increasingly dictate the behaviour of firms and change the basis of competitive rules. Thus, economic strategies of owner-investor management reconnect finance, ownership and corporate strategy in the firm but can disconnect corporate strategy from established stakeholder interests. The competitive demands of this activity may reinforce embedded patterns of industrial relations and comparatively limited approaches to involvement and participation by the HR function in business strategy. For example, see Kersley et al. (2006: 63) where it is reported that 47 per cent of British workplaces have a strategic plan that includes employment relations and the HR function where the HR function was involved in the formulation of the plan. However, 30 per cent of British workplaces have no such plan with another 18 per cent of workplaces having a strategic plan covering HR and employment relations issues that excluded the HR function from its formulation. There is no evidence to suggest that any firms governed by the PEBM or those in this in this study are likely to alter these exclusions, hence, many British firms operate as minimalist organisations in respect of HRM. Third, contemporary global financial crisis caused by the diffusion of subprime mortgages in the USA followed by the uncovering of the depth to Greek, Irish and Portuguese sovereign debt has the potential to destabilise real economies including institutional interests in the labour market, which are geographically, economically and politically unrelated to the source of such volatility (Clark, 2009b). Thus, financialisation provides a contextual background within which the PEBM has emerged across the British economy to reinforce embedded patterns of short-termism.

Diffusion of a PEBM template in portfolio firms by outside investors may encourage many of them to adopt internal structures or management tools that are similar to those present in other portfolio firms controlled by private equity and governed by the PEBM (see Morgan, 2009). However, disruption and reshaping may disconnect diffusion of such a template from the formal institutionalisation of practices associated with financial control in portfolio firms owned by private equity investors. That is, managers in portfolio firms may adopt, but not institutionalise, management strategies and policies informed by a PEBM template for portfolio firm operations. Here, the forceful role of private equity owners as a form of coercion may be a significant factor. That is, portfolio firms may become financialised assets, but this does not necessarily lead to a unitary implementation of the PEBM, even though owner-investors aspire to do so. As with DiMaggio and Powell's $(1983,1991)$ original formulation of coercive, mimetic and normative isomorphism, some practices may be adopted because they are associated with success whereas others may be adopted because they appear appropriate. That is, practices may be 'taken for granted routines' and assumed to be effective and present in subsidiaries, or in this case in portfolio firms (see Kostova, 1999). Updating these categories, Simmons et al. (2006) suggest that formulation and diffusion of innovative policies can be coercive resulting from the 
impact of powerful outsiders such as outsider-investor owners. However, coercion may be merely competitive where application is selective but aims to maintain competitive advantage as competitors are assumed to follow or are observed following a particular practice. Hence, competitive adoption does not necessarily equate to a full institutionalisation of a preferred template. In contrast to this, the competitive adoption of elements within a template may constitute learning from a 'best-practice' template as applied by competitors. Alternatively, learning may be vicarious, which is less rigorous and involves mimicking rather than formally adopting particular practices. Thus, a key question is the extent to which component parts of any template are actually implemented in portfolio firms rather than fully institutionalised in them. Processes such as coercive, competitive or vicarious adoption may be repeated and acquire similar characteristics and meaning wherein they become legitimised but not necessarily institutionalised. As a process of implementation codified and tacit diffusion encourages actors to 'take for granted' the appropriateness of generally defined activities or processes, for example, in this case, the appropriateness of a template for portfolio firm operations under private equity ownership. A disconnection may be present here as external actors may play a central role in the selection of specific organisational practices and processes (Kostova and Roth, 2002).

\section{RESEARCH METHOD AND DATA COLLECTION}

This study examines the diffusion of the PEBM from PEFs to portfolio firms to build on a clear conceptual framing of the PEBM (Clark, 2009a,b; Morrell and Clark, 2010; Rodrigues and Child, 2010) and its empirical application (Bailey et al., 2010; Clark, 2011). The theoretical framework establishes that under private equity ownership, investor and owner interests predominate over those of a wider group of stakeholders such as employees, customers, taxation authorities and the local community, but that this may not be institutionalised formally. Survey methods are capable of identifying broad categories of response, but they are less insightful for exploring complex chains of causation. Qualitative case studies can overcome some of these limitations by highlighting processes linking the behaviour of private equity owners to established characteristics in a portfolio firm. Similarly, case studies can highlight differences between the presence of a template in PEFs and the efforts to diffuse or institutionalise component parts of a template. In summary, detailed case studies avoid potential measurement errors that may occur in survey methods where there is little effort to distinguish between presence of a template and the implementation of a template. The empirical findings presented in the fourth section are based on interview data gathered from managers in eight portfolio firms in the UK - insurance and breakdowns services, high street sandwich provider, clothing retailer 1 and 2, engineering 1 and 2 department store and telecommunications - and five case studies of associated private equity owners or controllers (PEFs 1-5). A first round of interviews was used to semi-structure a template for portfolio firm operations around six coded categories. These headings were devised from first interview data analysis. The research questions and the findings that follow from these are capable of generalisation on the specific issue of diffusion of a template for the PEBM in portfolio firms for two reasons. First, 32 semi-structured interviews were conducted with managers in functions that have a direct bearing on transmission mechanisms and pressures for institutionalisation therein, for example, finance, marketing and customer and investor relations and HR. These interviews used a common interview template, and a further 10 interviews were conducted in the five PEFs. In each case, managers responsible for portfolio firm oversight management and the management of branch managers were interviewed twice over a period 
of 3 months. The questionnaires utilising a coded interview template and interviews were recorded, transcribed and coded on data analysis software. Second, a semi-structured format ensures that reporting of the diffusion of the PEBM, its manifestation in portfolio firms and the effect of this on workers and managers comes from the views of the interviewees, not the framework developed to examine these responses. The latter is merely used to order these responses.

\section{THE INSTITUTIONALISATION OF THE PEBM TEMPLATE IN PORTFOLIO FIRMS?}

\section{Empirical findings}

The findings presented here are based on two sources. First, interview data gathered from private equity practitioners and, second, interviews with managers in portfolio firms. Of the 10 private equity practitioners who were interviewed, 7 were general partners with lengths of tenure ranging from 1 year to 20 years. Seven of the practitioners, including partners and employees were graduates, and four of these had specialist graduate qualifications from universities in London. They were of mixed nationalities, but the four practitioners from two American owned PEFs were American citizens. Interestingly, most of the PEF practitioners and at least one from each of the five PEFs stated that much of the detailed work under each of the six contingency headings on the PEF template was actually handled by consultants regularly engaged by individual PEFs. Many private equity investors favour managing portfolio firms in accordance with the 'best-practice' strategy outlined in the British Venture Capital Association (BVCA)'s guidelines monitoring group (GLMG) document for effective portfolio firm management (GLMG, 2009: 16). This involves managing portfolio firms through a series of advisory panels or consultants on a contractual and transactional basis. For reasons of confidentiality and market sensitivity, it is not possible to be more precise than this. The interviews with private equity practitioners revealed that they had a preferred template for portfolio firms, which they did not always find it necessary or possible to fully implement. Each of the managing partners interviewed across the five PEFs described their role as 'acting on behalf of investors' by 'taking small or large stakes in underperforming or undervalued firms' and then seeking to 'influence' management to restructure operations and work organisation on the basis of a preferred template to improve investor and shareholder returns. However, all practitioners suggested that movement towards the preferred template for improved valueadded financial performance necessitated decisive restructuring under some headings. More critically, it became clear that improved financial performance referred primarily to the performance of the private equity, fund not necessarily the portfolio firm itself. That is, the revenue streams from efficiency savings or asset divestments were not automatically ploughed back into the portfolio firm. Across the five PEFs, measures to improve financial performance included asset disposals and associated downsizing, de-leveraging by share buy-backs funded by property leasing or pension scheme sales to the secondary market. More specifically, it became clear that a key aim in the process of change was to make investor and shareholder value the norm for senior managers by linking share price movements to executive compensation. All practitioners attributed poor performance or underperformance of listed firms to ineffective management and inappropriate patterns of corporate governance, particularly those patterns that institutionalised diverse stakeholder interests. Without exception in successive interviews, all the practitioners agreed that the schedule presented to them summarised their preferred view of portfolio firm operations. The template for preferred operations contains six contingencies, which are listed below. Details of the extent to which they were diffused in portfolio firms were provided by interview contacts in portfolio firms. 


\section{Private equity ownership template for portfolio firm operations}

1. Organisation downsizing; divestment and redundancies.

All five PEFs stated that they look for divestments and redundancies. However, across the eight portfolio firms, divestment and head count reductions via redundancy were actually implemented in only three cases. Therefore, while this practice was formally adopted by PEFs, it was only partially diffused by them in portfolio firms. In contrast to this, for portfolio firms' divestment and redundancy appeared as learning from competitors and vicarious learning that mimicked practices in other portfolio firms that an owner also controlled. Learning and mimicry appear as tacit vicarious learning in portfolio firms. This is the case because divestment and redundancy decisions were not the product of management agency within portfolio firms but outside agents, that is, new owner-investors.

2. Asset sales; franchise divestments, winding-up final salary pension schemes for new employees in portfolio firms; sale of existing schemes in the secondary private equity market, managing the portfolio firm's pension arrangements on a contractual basis.

Each of the eight portfolio firms was subject to some form of asset sale or franchise divestment. In the majority of cases, this included winding up final salary pension schemes for new employees and selling the existing scheme in the secondary private equity market and managing the portfolio firm's pension arrangements on a contractual basis. Hence, asset sales are formally instituted by the PEF template and are formally diffused in portfolio firms. However, as with organisational downsizing, this diffusion was not institutionalised within management agency in the portfolio firms because decisions over asset sales were made coercively by outside owner-investors and their advisors.

3. Financial engineering; transferring employees to new subsidiaries, transferring whole operating units of a portfolio firm to related or unrelated subsidiaries, loans to subsidiary firms, dividend re-capitalisations and share-buy backs.

Only three portfolio firms transferred employees to new subsidiaries whereas two of them transferred whole operating units of the portfolio firm to related or unrelated subsidiaries. In these cases, terms and conditions for existing employees were maintained whereas those for new starters had lower levels of employee entitlement. The presence of the latter was more prevalent than it first appeared as in some cases as an alternative to transfer existing employees were offered redundancy settlements. In addition, the same two firms entertained loans to subsidiary firms, dividend re-capitalisations and share-buy backs. Financial engineering was formally adopted by PEFs but only competitively diffused in portfolio firms rather than formally institutionalised. That is, financial engineering cannot be taken for granted any longer or given a common meaning across all eight portfolio firms. Specifically, the current climate of economic and financial crises makes 'taken for granted' methods of financial engineering impractical or inappropriate and, if utilised, may push a portfolio firm and its parent PEF into financial distress (see Clark, 2010).

4. Performance management; merit and performance-related pay and share options for managers.

Performance-related pay and share options were introduced by all portfolio firms. Performance management was formally adopted by PEFs and formally institutionalised in all portfolio firms. 
5. Team monitoring; appraisals and a refocusing of team priorities on cash flow and revenue streams institutionalised in portfolio firms as a technical and bureaucratic control administered by the HR function.

Appraisals and a refocusing of team priorities on cash flow and revenue streams were universally introduced in all eight portfolio firms. More focused outsider come coercive short-term monitoring was formally adopted by PEFs and coercively diffused, but therefore not institutionalised in portfolio firms.

\section{Management-worker relations}

Practitioners in two PEFs stated that they had no preference over workplace relations whereas partners in the other three PEFs stated that they preferred what industrial relations specialists refer to as unitary relations with the workforce. In addition to this, all the practitioners stated that if a portfolio firm was unionised, it is difficult to alter this arrangement without significant hostility from the workforce and related bad publicity. However, all practitioners stated that they were willing to deploy significant resources to prevent unionisation of a portfolio firm. In three PEFs, a clear preference was expressed (whatever the current position) that the operating performance of a portfolio firm depends on a unitary alignment of owner, manager and employee interests. Practitioners from private equity partnerships were quite open about this issue but often declined to spell out what it actually meant other than the rejection of pluralist stake holding approaches to decision making even where this approach remained in place post buyout. A partner in PEF 1 stated that in the UK, private equity owner-managers (such as themselves) have hired anti-union consultants to secure this position (see also Logan, 2008: 18). Alternatively, at PEF 4, a practitioner stated that UK private equity owners have used derecognition followed by re-recognition of a 'company union' to maintain pluralist relations in the workplace but on a 'lower road' model (Clark, 2011). A preferred template for industrial relations was formally adopted by PEFs and coercively diffused in portfolio firms (sometimes tacitly) rather than institutionalised by moving to unitary industrial relations. This appeared as a process of tacit attrition where diffusion involved ignoring substantive and proceduralised stakeholder interests institutionalised in collective agreements. Table 1 summarises the six contingencies in the PEF template for portfolio firms. Table 2 summarises the details of the process of diffusion in portfolio firms and draws on the interviews conducted with managers therein, and Figure 1 places the six contingencies in rank order of implementation in portfolio firms and summarises the form in which they are diffused into portfolio firms. The bracketed numbers relate to the ranking that partners in PEFs gave the six contingencies on the basis of previous implementation experiences.

\section{DISCUSSION}

In the UK, PEFs are unregulated limited partnerships (although a few PEFs are listed firms, for example, 3i). The absence of regulation heightens the deployment of managerial incentives and financial benchmarks that aim to outperform listed firms. More particularly, the absence of active regulation, beyond self-regulation by the private equity sector, poses few obstacles to the full institutionalisation of the PEBM in portfolio firms yet in the portfolio firms understudy, this was not necessarily the case. This finding demonstrates how observable disruptions and disconnects associated with the financialisation of the British economy shape HR practices to 
TABLE 1 Template for private equity business mode practitioners (PE1-5)

\begin{tabular}{|c|c|c|c|c|c|}
\hline & PE1 & PE2 & PE3 & PE4 & PE5 \\
\hline Organisation downsizing & Y & $\mathrm{Y}$ & $\mathrm{Y}$ & $\mathrm{Y}$ & $\mathrm{Y}$ \\
\hline Divestment unrelated, underperforming or peripheral units. & $\mathrm{Y}$ & $\mathrm{Y}$ & $\mathrm{Y}$ & $\mathrm{Y}$ & $\mathrm{Y}$ \\
\hline Looking for head count reduction (i.e. redundancy) & Y & Y & Y & Y & $\mathrm{Y}$ \\
\hline $\begin{array}{l}\text { Asset sales } \\
\text { Pension fund }\end{array}$ & Y & Y & Y & Y & Y \\
\hline \multicolumn{6}{|l|}{ Financial engineering } \\
\hline Recapitalisation & $\mathrm{Y}$ & $\mathrm{Y}$ & $\mathrm{Y}$ & $\mathrm{Y}$ & $\mathrm{Y}$ \\
\hline Share buy-backs & $\mathrm{Y}$ & $\mathrm{Y}$ & Y & $\mathrm{Y}$ & $\mathrm{Y}$ \\
\hline Loans to associated portfolio firms & & Y & Y & Y & Y \\
\hline Transfers to subsidiary & Y & Y & $\mathrm{Y}$ & Y & Y \\
\hline \multicolumn{6}{|l|}{ Employees } \\
\hline \multicolumn{6}{|l|}{ Operating divestments units } \\
\hline Performance management & $\mathrm{Y}$ & $\mathrm{Y}$ & $\mathrm{Y}$ & $\mathrm{Y}$ & $\mathrm{Y}$ \\
\hline \multicolumn{6}{|l|}{ Exit options } \\
\hline \multicolumn{6}{|l|}{ Share options } \\
\hline \multicolumn{6}{|l|}{ Buy-in options } \\
\hline \multicolumn{6}{|l|}{ Sweet equity } \\
\hline \multicolumn{6}{|l|}{ Share price linked remunerations $(£$ or $€$ ) } \\
\hline \multicolumn{6}{|l|}{ Performance related pay } \\
\hline \multicolumn{6}{|l|}{ Individual } \\
\hline \multicolumn{6}{|l|}{ Team } \\
\hline \multicolumn{6}{|l|}{ Unit } \\
\hline Team monitoring & Y & Y & $\mathrm{Y}$ & $\mathrm{Y}$ & Y \\
\hline \multicolumn{6}{|l|}{ Refocused team priority (cash flow and revenue stream) } \\
\hline \multicolumn{6}{|l|}{ Weekly team briefing and targets } \\
\hline \multicolumn{6}{|l|}{ Monthly team briefing and target assessment } \\
\hline \multicolumn{6}{|l|}{ Direct (individual or team) communication and involvement } \\
\hline Management appraisals annual (A) 6 months (6) or (3) & Y A & Y A & Y A & Y 6 & Y 6 \\
\hline Monitored employee appraisal re-target & $\mathrm{Y}$ & $\mathrm{Y}$ & $\mathrm{Y}$ & Y & Y \\
\hline Management-worker relations [non-union (NU, No-Pref, NP)] & NP & NU & NU & NU & $\mathrm{NP}$ \\
\hline
\end{tabular}

perhaps limit the more optimistic, coherent and integrated view of HRM under private equity ownership.

The diffusion of financial incentives for managers and workers in portfolio firms rests on private equity owners and associated consultants, that is, powerful outsiders, persuading senior incumbent managers to accept a unilateral refocusing of business and HR strategies, otherwise termed decisive restructuring. Interviews in portfolio firms established that this strategy involved segmenting production or provision strategies and responsibility for these from the majority of the workforce often including many middle managerial grades, in effect, redefining the core-insider periphery-outsider boundaries. Managers in portfolio firms suggested that this approach limited the ability of workers and some middle managers to actively participate in the conduct and formulation of innovative business and HR strategies. This exclusion benefited new owner-investors because it reduced their dependence on incumbent managers. This enabled external management teams and advisory groups to focus on driving decisive change in portfolio firms without the active cooperation of the majority of a workforce. These more 
TABLE 2 Details of template diffusion in portfolio firms (PFs)

\begin{tabular}{|c|c|c|c|c|c|c|c|c|}
\hline & $\begin{array}{l}\text { PF1 } \\
\text { UK }\end{array}$ & PF2 & PF3 & PF4 & PF5 & PF6 & PF7 & PF8 \\
\hline Organisation downsizing & Y & Y & $\mathrm{Y}$ & Y & $\mathrm{Y}$ & $\mathrm{Y}$ & $\mathrm{Y}$ & $\mathrm{Y}$ \\
\hline $\begin{array}{l}\text { Divestment unrelated, underperforming } \\
\text { or peripheral units. }\end{array}$ & $\mathrm{N}$ & $\mathrm{N}$ & $\mathrm{Y}$ & $\mathrm{N}$ & $\mathrm{N}$ & $\mathrm{N}$ & $\mathrm{Y}$ & $\mathrm{Y}$ \\
\hline $\begin{array}{l}\text { Head count reduction (i.e. redundancy) } \\
\text { actually implemented (I) }\end{array}$ & $\mathrm{N}$ & $\mathrm{N}$ & $\mathrm{Y}$ & Y I & $\mathrm{N}$ & $\mathrm{N}$ & $\mathrm{N}$ & Y I \\
\hline Asset sales & Y & Y & Y & Y & Y & Y & Y & Y \\
\hline Pension fund & Y & Y & Y & Y & $\mathrm{N}$ & $\mathrm{N}$ & $\mathrm{N}$ & Y \\
\hline $\begin{array}{l}\text { Property portfolio or franchise } \\
\text { divestments }\end{array}$ & $\mathrm{N}$ & $\mathrm{N}$ & $\mathrm{N}$ & $\mathrm{N}$ & Y & $\mathrm{Y}$ & $\mathrm{Y}$ & $\mathrm{N}$ \\
\hline \multicolumn{9}{|l|}{ Financial engineering } \\
\hline Recapitalisation & $\mathrm{N}$ & $\mathrm{N}$ & $\mathrm{N}$ & $\mathrm{N}$ & Y & $\mathrm{Y}$ & $\mathrm{Y}$ & $\mathrm{Y}$ \\
\hline Share buy-backs & $\mathrm{N}$ & $\mathrm{N}$ & $\mathrm{N}$ & $\mathrm{N}$ & $\mathrm{N}$ & $\mathrm{N}$ & $\mathrm{Y}$ & $\mathrm{Y}$ \\
\hline $\begin{array}{l}\text { Loans to associated portfolio firms } \\
\text { Transfers to subsidiary }\end{array}$ & $\mathrm{N}$ & $\mathrm{N}$ & $\mathrm{N}$ & $\mathrm{N}$ & $\mathrm{N}$ & Y & $\mathrm{Y}$ & Y \\
\hline Employees & $\mathrm{N}$ & $\mathrm{N}$ & $\mathrm{N}$ & $\mathrm{N}$ & $\mathrm{N}$ & $\mathrm{Y}$ & $\mathrm{Y}$ & $\mathrm{Y}$ \\
\hline Operating divestments units & $\mathrm{N}$ & $\mathrm{N}$ & $\mathrm{N}$ & $\mathrm{N}$ & $\mathrm{N}$ & $\mathrm{N}$ & $\mathrm{Y}$ & $\mathrm{Y}$ \\
\hline \multicolumn{9}{|l|}{ Performance management } \\
\hline Exit options & $\mathrm{N}$ & $\mathrm{N}$ & $\mathrm{N}$ & $\mathrm{N}$ & $\mathrm{N}$ & Y & $\mathrm{N}$ & $\mathrm{N}$ \\
\hline Share options & Y & Y & Y & Y & Y & Y & $\mathrm{N}$ & $\mathrm{N}$ \\
\hline Buy-in options & Y & Y & Y & Y & Y & Y & $\mathrm{N}$ & $\mathrm{N}$ \\
\hline Sweet equity & $\mathrm{N}$ & $\mathrm{N}$ & $\mathrm{N}$ & $\mathrm{N}$ & $\mathrm{N}$ & $\mathrm{Y}$ & $\mathrm{N}$ & $\mathrm{N}$ \\
\hline $\begin{array}{l}\text { Share price linked remunerations } \\
\qquad(£ \text { or } €)\end{array}$ & $\mathrm{N}$ & $\mathrm{N}$ & $\mathrm{N}$ & $\mathrm{N}$ & $\mathrm{N}$ & $\mathrm{Y}$ & $\mathrm{N}$ & $\mathrm{N}$ \\
\hline Performance related pay & $\mathrm{Y}$ & Y & $\mathrm{Y}$ & $\mathrm{Y}$ & Y & $\mathrm{Y}$ & $\mathrm{Y}$ & Y \\
\hline Individual & Y & $\mathrm{Y}$ & $\mathrm{Y}$ & Y & $\mathrm{Y}$ & $\mathrm{Y}$ & $\mathrm{Y}$ & $\mathrm{Y}$ \\
\hline Team & $\mathrm{N}$ & $\mathrm{N}$ & $\mathrm{N}$ & $\mathrm{N}$ & $\mathrm{N}$ & $\mathrm{N}$ & $\mathrm{N}$ & $\mathrm{N}$ \\
\hline Unit & $\mathrm{N}$ & $\mathrm{N}$ & $\mathrm{N}$ & $\mathrm{N}$ & $\mathrm{N}$ & $\mathrm{N}$ & $\mathrm{N}$ & $\mathrm{N}$ \\
\hline \multicolumn{9}{|l|}{ Team monitoring } \\
\hline $\begin{array}{l}\text { Refocused team priority (cash flow and } \\
\text { revenue stream) }\end{array}$ & $\mathrm{Y}$ & $\mathrm{Y}$ & Y & $\mathrm{Y}$ & Y & $\mathrm{Y}$ & $\mathrm{Y}$ & $\mathrm{Y}$ \\
\hline Weekly team briefing and targets & $\mathrm{N}$ & $\mathrm{N}$ & $\mathrm{N}$ & $\mathrm{N}$ & Y & $\mathrm{Y}$ & $\mathrm{N}$ & $\mathrm{Y}$ \\
\hline $\begin{array}{l}\text { Monthly team briefing and target } \\
\text { assessment }\end{array}$ & $\mathrm{N}$ & $\mathrm{N}$ & $\mathrm{N}$ & Y & Y & Y & $\mathrm{N}$ & Y \\
\hline $\begin{array}{l}\text { Direct (individual or team) } \\
\text { communication and involvement }\end{array}$ & $\mathrm{N}$ & $\mathrm{N}$ & $\mathrm{N}$ & $\mathrm{N}$ & $\mathrm{N}$ & $\mathrm{N}$ & $\mathrm{Y}$ & Y \\
\hline $\begin{array}{l}\text { Management appraisals annual (A) } 6 \\
\text { months (6) or (3) }\end{array}$ & Y & Y & Y & Y & Y & Y & Y 6 & Y 6 \\
\hline Monitored employee appraisal re-target & $\mathrm{Y}$ & $\mathrm{Y}$ & $\mathrm{Y}$ & $\mathrm{Y}$ & $\mathrm{N}$ & $\mathrm{N}$ & $\mathrm{N}$ & $\mathrm{N}$ \\
\hline \multicolumn{9}{|l|}{ Management-worker relations } \\
\hline \multicolumn{9}{|l|}{ Actual situation in PFs } \\
\hline Unionised & & & & & & $\mathrm{Y}$ & Y & $\mathrm{Y}$ \\
\hline Non-union & Y & $\mathrm{Y}$ & Y & Y & Y & & & \\
\hline Derecognition & & & & & Y & & & \\
\hline Works council & & & Y & Y & & Y & Y & Y \\
\hline Use of consultants & $\mathrm{N}$ & $\mathrm{N}$ & $\mathrm{N}$ & $\mathrm{N}$ & $\mathrm{N}$ & $\mathrm{N}$ & $\mathrm{N}$ & Y \\
\hline
\end{tabular}


FIGURE 1 Rank order implementation of private equity business model template contingencies in portfolio firms

\section{1, Performance Management. Formally Institutionalised in PEFs and all portfolio Firms. (2)}

2, Team Monitoring. Formally adopted and coercively diffused in all portfolio firms by powerful outsiders. (3)

3, Asset Sales. Formally adopted by PEFs and coercively diffused in all portfolio firms. (5)

4, Management-worker Relations. Formally adopted by three of the five PEFs but coercively if tacitly diffused in all portfolio firms. (4)

5, Financial Engineering. Formally adopted by PEFs and competitively diffused in three of the eight portfolio firms. (1)

6, Organisational Downsizing. Formally adopted by PEFs and diffused as learning in three of the eight portfolio firms. (6)

nuanced empirical observations are instructive in explaining why performance management and team-monitoring components of the PEBM were universally diffused across portfolio firms whether formally institutionalised or coercively diffused. That is, where portfolio firms apparently do as others do on the basis of coercive pressures emanating from the powerful outsiders - the PEFs and their investors. Moreover, institutionalised or coercive diffusion is underpinned by the imperative of fund management incentives in private equity owners that help to create the much cited 'alignment of interests' between outsider owner-investors and core employees. Across all eight portfolio firms, examples of incentive alignment were evident to the extent that senior managers in portfolio firms shared owner-investor concerns to raise the market capitalisation of a firm, even though measures associated with this process were not fully institutionalised in any of them in a formal manner. As has been observed in other research, managers who have a defined responsibility and authority can suddenly find themselves subject to a more explicit managerial hierarchy. While they are simultaneously managers, they are also managed, in some cases, via incentives, within a rigid system of innovative rules and job controls imposed on them rather than institutionalised from the outside (see McCann et al., 2010: 349)

Significant competitive implications of a change in controlling stakeholder fell on employment relations for managerial grades in portfolio firms, HR managers in particular. In three of the portfolio firms, new controlling stakeholders managed the firms using advisory teams of consultants in the manner identified by the GLMG, which identifies the deployment of advisory teams as the most 'economical' way for new investors to comply with transparency regulations in respect of decision making and employee consultation. These findings bear out recent theoretical arguments and empirical findings on owner-investor interests under the PEBM, which suggest that new owners are unlikely to negotiate or even speak to other stakeholders such as creditors, third-party shareholders, customers or trade unions (Clark, 2009b; Harner, 2008: 739, 760-762). Across the eight portfolio firms, an immediate competitive and coercive effect of new investors was that intermediaries, advisory teams or consultants reflected the PEBM and acted on behalf of the investors and their lenders not the portfolio firm and established stakeholders. New owner-investors and their managerial intermediaries 'hit the ground running' giving incumbent managers in portfolio firms only a short period of time to react to and internalise the new competitive environment within which they now operate. In 
effect, this process breaks established implicit contracts between and within management and the workforce, making it more difficult for employers to keep their established side of the bargain. This breach is inherently short term, rent seeking and disciplinary in its effects on firm level operations. The ownership context for these behaviours compels owners and their managerial agents to devote a disproportionate amount of time to the short-term impact of their investment decision. Operational and functional restructuring is likely to follow this to improve cash flow, increase current share price and control management and workers by reducing opportunism opportunities. This creates an external owner focused frame for management self-interest at the expense of other stakeholders. Hence, it is likely to be the case that the disruptions and disconnections associated with financialisation, in particular, a transaction based approach to acquisitions further embeds short-termist features of the British economy. These features emphasise minimalist engagement with resource-based approaches to HRM, which require a long-term commitment and perspective on the part of private equity investors to portfolio firms.

Empirically, for a portfolio firm, diffusion of the PEBM template varies from formal adoption to vicarious learning and centres on the ability of investor-owner-managers to achieve ceremonial if not institutional alignment between investor-owner interests, those of managers and workers in portfolio firms. As recent studies demonstrate downsizing, asset sales and financial engineering represent three areas of activity in which private equity investors exercise efficiencies in management practice over listed or other private firms (see Acharya et al., 2009; Achleitner etal., 2009; Bacon et al., 2010). In the cases under consideration, asset sales were coercively diffused in all portfolio firms to represent a clearcut example of decisive restructuring by powerful outsiders. In contrast to this, financial engineering and organisational downsizing were competitively diffused and diffused as organisational learning in only three of the eight case firms on the basis of what other private equity backed firms undertook or efforts to mimic this process. However, while private equity-backed firms do exercise efficiencies over listed firms in asset sales, financial engineering and organisational downsizing, these activities were ranked only third, fifth and sixth in the case studies. For example, asset sales illustrate a further case of how disconnects between the impact of financialisation across the economy shape firm-level practice. That is, the financial demands of external owners dictate behaviour in portfolio firms but not necessarily in the direction of resource based approaches as asset sales, performance management and reconfigured approaches to team monitoring each appear as transactionoriented short-term disintegrated policies.

Moreover, the current financial climate reduces the utility of leverage and debt loading to secure short-term financial returns. This, combined with efforts to avoid financial distress, concentrates portfolio firm-level imperatives on tighter methods of performance management and team monitoring. Both of these aim to improve cash flow and returns to investors and represent emergent forms of decisive restructuring that rely less on leverage and rely more on renegotiating industrial relations agreements with employees either coercively or tacitly.

\section{CONCLUSIONS}

Two research questions informed this study. First, how and in what form is the PEBM diffused in portfolio firms; and second, as a method of financial control, in what way is this experienced by managers and employees. The answer to the first question is that while PEFs may have a defined template for portfolio firm operations, it is diffused in various ways and to various degrees but not necessarily institutionalised in portfolio firms, even though the 
template is institutionalised in the culture of PEFs. That is, the diffusion of business models in portfolio firms can be disconnected from economic and financial imperatives, but nonetheless component parts of the template such as performance management can be formally institutionalised whereas team monitoring and more unitary approaches to employment relations may be formally and coercively and tacitly codified in portfolio firms. Equally significant is the shared view of how to improve the financial performance of a portfolio firm prevalent among PEF practitioners, be they partners, managers or consultants. These views, which in amalgamation create the portfolio firm template, represent a common starting point among this group within which there is a recognition that it may not always be possible or desirable to move towards this template. The key point is that financial improvements in the management of $\mathrm{HR}$ in portfolio firms are not necessarily efficiency savings the benefits of which are used to improve portfolio firm operations. Rather, the savings represent returns to improve the performance of the private equity fund financing the portfolio firm. Balance sheet restructuring of this type occurs in listed firms too. What appears to be different in firms governed by the PEBM is that the revenue streams of financial engineering associated with this process go beyond the portfolio firm as an entity to external investors not necessarily shareholders in a firm. Moreover, any debts incurred within portfolio firm restructuring and refinancing remain with the firm, not its current owners. While these strategies appear to represent a coherent 'best practice' to portfolio firm restructuring, firms that are not governed by the PEBM have successfully 'mimicked' strategies associated with the model to raise efficiency levels (Acharya et al., 2009; Achleitner et al., 2009). This suggests that diffusion of this 'best practice' in restructuring and financial engineering may be adopted by firms listed or otherwise which are not governed by the PEBM. The answer to the second question suggests the effects on managers and employees of decisive restructuring in individual template contingencies appear more enduring than adherence to the template of the model itself. In the case of the PEBM, managers and employees are subject to tighter financial performance management, coercive institutionalisation of more unitary preferences for industrial relations - not necessarily always enacted and more draconian short-termism. That is, the best practice credentials of the PEBM may not be institutionalised formally in portfolio firms, but as a manifestation of financialisation on managers and workers, the component part effects of such decisive restructuring on employees are more evident than the PEBM template as a whole.

\section{Acknowledgements}

Thanks to HRMJ referees, Paul Kenney, Maria Ludkin, Paul Maloney at the GMB Union, Members of the Treasury Select Committee on Private Equity, June 2007. Some initial interview contacts were secured on the ESRC funded project R000238350. Office management by Jane Whitmarsh, Finance office management by Jacqui Ward and Christine Horton.

\section{REFERENCES}

Acharya, V., Kehoe, D. and Reyner, M. (2009). 'Private equity vs. PLC boards: a comparison of practices and effectiveness, a summary of research findings'. Journal of Applied Corporate Finance, 21: $1,45-56$.

Achleitner, A.-K., Braun, R., Engel, N., Figge, C. and Tappeiner, F. (2010). 'Value creation drivers in private equity buyouts: Empirical evidence from Europe', Journal of Private Equity, 13: 2, 17-27.

Appelbaum, E., Batt, R. and Clark, I. (2011). 'Collateral damage and financial capitalism: Cadbury, EMI, Mervyn's and Stuyvesant Town/Peter Cooper Village'. Presented at the British Journal of 
Industrial Relations 50th Anniversary Conference 'Across Boundaries: An Interdisciplinary Conference on Global Challenges Facing Workers and Employment Research', London School of Economics, 12-13 December 2011.

Bacon, N., Wright, M., Scholes, L. and Meuleman, M. (2010). 'Assessing the impact of private equity on industrial relations in Europe'. Human Relations, 63: 9, 1343-1370.

Bailey, D., Clark, I. and De Ruyter, A. (2010). 'Private equity and the flight of the Phoenix Four - the Collapse of MG Rover'. The Cambridge Journal of Regions, Economy and Society, 3: 3, 1-15.

Bogle, J. (2005). The Battle for the Soul of Capitalism, New Haven, CT: Yale University Press.

Centre for Management Buy-Out Research (2008). Going Down. CMBOR Quarter Four News and Updates, http://www.cimbor.com, accessed June 2010.

Centre for Management Buy-Out Research (2010a). UK Market Sees Lowest Buyout Value Since 1995. CMBOR press release, 19 January 2010, http://www.cimbor.com, accessed June 2010.

Centre for Management Buy-Out Research (2010b). Value of UK Buy-Outs Nears 2008 Level. CMBOR press release, 11 October 2010, http://www.cimbor.com, accessed January 2011.

Clark, I. (2009a). 'Owners not managers: Disconnecting managerial capitalism? Understanding the private equity business model'. Work, Employment and Society, 23: 4, 359-378.

Clark, I. (2009b). 'The private equity business model and associated strategies for HRM: Evidence and implications'. The International Journal of Human Resource Management, 20: 10, 2030-2048.

Clark, I. (2010). 'Distress and trafficking in new capitalism: The fate of private equity portfolio firms in economic crisis?' in A. Watt and B. Galgoczi (eds), Private Equity and Financialization: Their Impact on the Real Economy, Brussels: ETUC.

Clark, I. (2011). 'Private equity, union recognition and value extraction at the AA'. Industrial Relations Journal, 42: 1, 36-50.

DiMaggio, P. and Powell, W. (1983). 'The iron cage re-visited: institutional isomorphism and collective rationality in organizational fields'. American Sociological Review, 48: 2, 161-173.

DiMaggio, P. and Powell, W. (eds) (1991). The New Institutionalism in Organizational Analysis, Chicago, IL: University of Chicago Press.

Dobbin, F. and Zorn, D. (2005). 'Corporate malfeasance and the myth of shareholder value'. Political Power Social Theory, 17: 179-198.

Dore, R. (2008). 'Financialisation of the global economy'. Industrial and Corporate Change, 17: 6, 1097-1112.

Epstein, G. (2005). 'Introduction', in G. Epstein (ed.), Financialization and the World Economy, Cheltenham: Elgar, pp. 1-17.

Fligstein, N. (2001). The Architecture of Markets, Princeton NJ: Princeton University Press.

Folkman, P., Froud, J., Johal, S. and Williams, K. (2007). 'Working for themselves: capital market intermediaries and present day capitalism'. Business History, 49: 4, 552-572.

Folkman, P., Froud, J., Williams, K. and Johal, S. (2009). 'Private equity levered on capital or levered on labour'. Journal of Industrial Relations, 51: 4, 517-529.

Froud, J. and Williams, K. (2007). 'Private equity and the culture of value extraction'. New Political Economy, 12: 3, 405-419.

Gilligan, J. and Wright, M. (2010). Private Equity De-Mystified: An Exploratory Guide, 2nd edn, London: ICAEW.

GLMG (Guidelines Monitoring Group) (2009). Private Equity Monitoring on Transparency and Disclosure. First Report, London, http://www.Walker-gmg.co.uk, accessed December 2009.

Goyer, M. (2006). 'Varieties of institutional investors and national models of capitalism: the transformation of corporate governance in France and Germany'. Politics and Society, 34: 3, 399-430.

Harner, M. (2008). 'Corporate governance and public policy implications of activist distressed debt investing'. Fordham Law Review, 77: 2, 703-775.

Jensen, M. (1989). 'The eclipse of the public corporation'. Harvard Business Review, September-October, 61-74.

Jensen, M. (2007). A Theory of the Firm: Governance, Residual Claims and Organizational Forms, Cambridge, MA: Harvard University Press. 
Jensen, M. and Murphy, K. (2009). CEO Pay and What to Do about It, Cambridge, MA: Harvard Business School Press.

Kersley, B., Alpin, C., Forth, J., Bryson, A., Bewley, H., Dix, G. and Oxenbridge, S. (2006). Inside the Workplace: Findings from the 2004 Workplace Employment Relations Survey, London: Routledge.

Kostova, T. (1999). 'Transnational transfer of strategic organizational practice: a contextual perspective'. Academy of Management Review, 24: 2, 308-324.

Kostova, T. and Roth, K. (2002). 'Adoption of an organization practice by subsidiaries of multinational corporations'. Academy of Management Journal, 45: 2, 215-233.

Krippner, G. (2005). 'The financialization of the American economy'. Socio-Economic Review, 3: 2, 173-208.

Logan, J. (2008). US Anti-Union Consultants: A Threat to the Rights of British Workers. Trade Union Congress, http://www.tuc.org.uk, accessed November 2008.

McCann, L., Hassard, J. and Morris, J. (2010). 'Restructuring managerial labour in the USA, the UK and Japan: challenging the salience of varieties of capitalism'. British Journal of Industrial Relations, 48: 2, 347-374.

Morgan, G. (2009). 'Private equity in the UK context'. Transfer: European Review of Labour and Research, 15: 2, 209-227.

Morrell, K. and Clark, I. (2010). 'Private equity and the public good'. The Journal of Business Ethics, 96, 249-266.

O'Sullivan, M. (2000). Contests for Corporate Control: Corporate Governance and Economic Performance in the United States and Germany, Oxford: Oxford University Press.

Palley, T. (2009). 'America's exhausted paradigm: Macroeconomic causes of the financial crisis and Great Recession', New America Contract Policy Paper, Washington, DC: New America Foundation.

PSE Socialist Group in the European Parliament (2007). Hedge Funds and Private Equity: A Critical Analysis, Draft Report, March, Brussels, European Parliament.

Rodrigues, S. and Child, J. (2010). 'Private equity, the minimalist organization and the quality of employment relations'. Human Relations, 63: 9, 1321-1342.

Schliefer, A. and Summers, L.H. (1988). 'Breach of trust in hostile takeovers', in A.J. Auerbach (ed.), Corporate Takeovers: Causes and Consequences, Cambridge, MA: National Bureau of Economic Research, pp. 33-68.

Simmons, B., Dobbin, F. and Garret, G. (2006). 'The globalization of liberalisation: policy diffusion in the international political economy'. International Organization, 60: 4, 781-810.

Sisson, K. and Purcell, J. (2010). 'Management: caught between competing views of the organization', in T. Colling and M. Terry (eds), Industrial Relations Theory and Practice, Oxford: Blackwell, pp. 81-106.

Soros, G. (2008). The New Paradigm for Financial Markets - The Credit Crisis of 2008 What It Means, New York: Public Affairs Books.

The Walker Report (2007). 'Guidelines for disclosure \& transparency in private equity'. London: British Venture Capitalist Association.

Thompson, P. (2003). 'Disconnected capitalism: or why employers can't keep their side of the bargain'. Work, Employment and Society, 17: 2, 359-378.

Thornton, P. (2007). Inside the Black Box: Shedding the Light on Private Equity. London: The Work Foundation, http://www.theworkfoundation.org, accessed January 2008.

Watt, A. and Galgoczi, B. (2009). 'Financial capitalism and private equity - a new regime?' Transfer, 15: 2, 189-208.

Wilson, N., Wright, M. and Cressy, R. (2010). Private Equity and Insolvency, London: British Venture Capital and Private Equity Association, April.

World Economic Forum (2008). The Global Impact of Private Equity. Working papers volume 1. WEF, Switzerland, http://www.weforum.org, accessed March 2008.

Wright, M., Bacon, N. and Amess, K. (2009). 'Private equity and buy-outs: employment, remuneration and other HRM practices'. Journal of Industrial Relations, 51: 4, 501-515. 